\title{
Dermoskeletics to preserve mobility and function in inclusion body myositis
}

Océane Landon-Cardinal, MD, François Prince, PhD, Stéphane Bédard, PEng, MSc, Olivier Benveniste, MD, PhD, and Marie Hudson, MD, MPH

Neurology ${ }^{\circledR}$ 2018;91:760. doi:10.1212/WNL.0000000000006365

A 45-year-old man developed gradual onset of finger flexors and quadriceps weakness. AntiNT5C1A antibody was positive, and muscle biopsy was consistent with inclusion body myositis. Options to preserve his mobility were explored. The Dermoskeleton uses high-end sensors and advanced artificial intelligence to detect the user's mobility intentions and generate synchronized assistance at the motorized knees. The device considerably improved the patient's 6-minute walk test (720-790 m) and stair climbing capacity (69-140 steps per minute) (videos 1 and 2), as a result of both assistance (primary) and bracing (secondary) factors. Advancing biomechanical technology provides novel options to preserve mobility and function for patients with neuromuscular diseases.

\section{Author contributions}

O. Landon-Cardinal, F. Prince, S. Bédard, and M. Hudson: conceptualization and design. O. Landon-Cardinal, F. Prince, and M. Hudson: acquisition of data. O. Landon-Cardinal, F. Prince, O. Benveniste, and M. Hudson: analysis and interpretation of data. O. LandonCardinal, F. Prince, S. Bédard, O. Benveniste, and M. Hudson: critical revision of the manuscript for important intellectual content.

\section{Acknowledgment}

The authors specially thank the PERFORM Centre, Concordia University, for providing the ideal spaces for shooting these videos and for providing an ideal research environment.

\section{Study funding}

No targeted funding reported.

\section{Disclosure}

The authors report no disclosures relevant to the manuscript. Go to Neurology.org/ $\mathrm{N}$ for full disclosures.

\author{
Correspondence \\ Dr. Landon-Cardinal \\ o.landoncardinal@ \\ gmail.com
}

MORE ONLINE

- Video

From the Hôpital Pitié-Salpêtrière (O.L.-C., O.B.), AP-HP, Department of Internal Medicine and Clinical Immunology, Inflammation-Immunopathology-Biotherapy Department (I2B), East Paris Neuromuscular Diseases Reference Center, Inserm U974, France; Departments of Kinesiology and Surgery (F.P.), University of Montreal, B-Temia Inc. (S.B.), Québec City, and Division of Rheumatology (M.H.), Department of Medicine, Jewish General Hospital, Lady Davis Institute, Montréal, Québec, Canada. 


\section{Neurology}

\section{Dermoskeletics to preserve mobility and function in inclusion body myositis Océane Landon-Cardinal, François Prince, Stéphane Bédard, et al. Neurology 2018;91;760 \\ DOI 10.1212/WNL.0000000000006365}

This information is current as of October 15, 2018

\section{Updated Information \& Services \\ Subspecialty Collections}

Permissions \& Licensing

Reprints including high resolution figures, can be found at: http://n.neurology.org/content/91/16/760.full

This article, along with others on similar topics, appears in the following collection(s):

All Neuromuscular Disease

http://n.neurology.org/cgi/collection/all_neuromuscular_disease Autoimmune diseases

http://n.neurology.org/cgi/collection/autoimmune_diseases

Muscle disease

http://n.neurology.org/cgi/collection/muscle_disease

Information about reproducing this article in parts (figures,tables) or in its entirety can be found online at:

http://www.neurology.org/about/about_the_journal\#permissions

Information about ordering reprints can be found online:

http://n.neurology.org/subscribers/advertise

Neurology ${ }^{\circledR}$ is the official journal of the American Academy of Neurology. Published continuously since 1951, it is now a weekly with 48 issues per year. Copyright (O) 2018 American Academy of Neurology. All rights reserved. Print ISSN: 0028-3878. Online ISSN: 1526-632X.

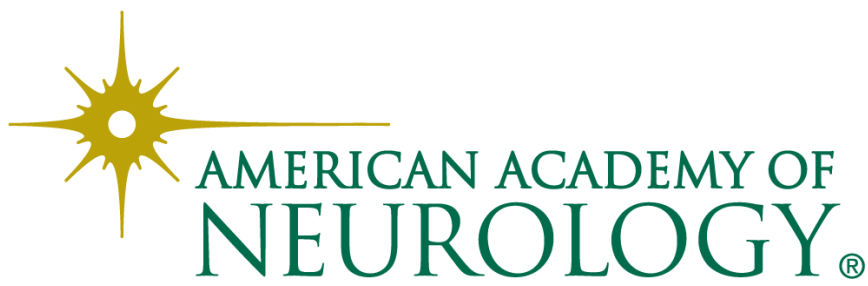

